\title{
A Case of a Central Giant Cell Granuloma in the Right Zygomatic Bone
}

\author{
Jong Yeop Seong, Seong Min Jin, Jae Gu Kim, and Dong Hoon Lee \\ Department of Otorhinolaryngology-Head and Neck Surgery, Chonnam National University Medical School \& \\ Chonnam National University Hwasun Hospital, Hwasun, Korea
}

\section{우측 광대뼈에 발생한 중심 거대 세포 육아종 1 예}

성종엽·진성민 · 김재구 · 이동훈

전남대학교 의과대학 화순전남대학교병원 이비인후-두경부외과학교실

\author{
Received March 30, 2017 \\ Revised May 5, 2017 \\ Accepted May 18, 2017 \\ Address for correspondence \\ Dong Hoon Lee, MD, PhD \\ Department of Otorhinolaryngology- \\ Head and Neck Surgery, \\ Chonnam National University \\ Medical School \& \\ Chonnam National University \\ Hwasun Hospital, \\ 322 Seoyang-ro, Hwasun-eup, \\ Hwasun 58128, Korea \\ Tel $+82-61-379-8190$ \\ Fax $+82-61-379-8199$ \\ E-mail leen31@hanmail.net
}

\section{서 론}

거대 세포 육아종은 대부분 악골에 발생하는 비신생성 양성 종양으로 드물게 다른 두개골부에서 발생할 수 있다. ${ }^{1)}$ 국내 에서는 최근까지 상악동에서 발생한 4 예의 거대 세포 육아종 이 보고되었으나, ${ }^{1-4)}$ 광대뼈에서 발생한 거대 세포 육아종은 보고되지 않았다. 최근 저자들은 우측 광대뼈에서 발생한 중 심 거대 세포 육아종을 발견하여, 치험하였기에 문헌고찰과 함께 보고하는 바이다.

This is an Open Access article distributed under the terms of the Creative Commons Attribution Non-Commercial License (https://creativecommons.org/licenses/by-nc/4.0) which permits unrestricted non-commercial use, distribution, and reproduction in any medium, provided the original work is properly cited.
The central giant cell granuloma is a benign tumor seen generally in the mandible, but rarely in other cranial bones. Herein, we present a 51-year-old man with central giant cell granuloma in the right zygomatic bone. Physical and radiologic examinations of the central giant cell difficult. Therefore, clinicians should consider the possibility that central giant cell granuloma may occur in the zygomatic bone mimicking other more frequently observed lesions. Korean J Otorhinolaryngol-Head Neck Surg 2018;61(11):615-8

Key Words Benign tumor $\cdot$ Central giant granuloma $\cdot$ Zygoma. 
물을 파괴하는 종양이 관찰되었다(Fig. 1). 양전자 방출 단층 촬영상 우측 전이개 부근에 연부조직 및 턱관절 주위의 악성 의심소견 관찰되었고 이외에 다른 장기의 전이는 저명하게 관찰되지 않았다(Fig. 2).

본원에서 재시행한 세침흡인검사상 고도의 암종이 나와, 우 측 안면부 악성종양 의심하에 전신마취하 우측이하선 천엽 절제술 및 광대 부위 종양 제거술을 시행하기로 하였다. 전신 마취하에 우측 이주 및 귓볼과 흥쇄유돌근을 따라 피부 절개 후에 이하선을 확인하였고, 주변을 박리하여 안면신경의 분지 를 확인하며 이하선 천엽을 제거하였다. 이후 안면신경의 하방 에 존재하는 종양을 확인하였고, 종양은 협골 및 주변 조직 과 비교적 경계가 뚜렷하여 특별한 문제없이 종양을 완전히 적출할 수 있었다(Fig. 3). 조직병리 소견상 다핵 파골성 거대 세포와 버팀질에 타원 및 바늘 모양의 단핵 세포, 혈철소 반점 침착이 보이는 중심 거대 세포 육아종으로 진단되었다(Fig. 4). 환자는 술 후 안면신경 마비 등의 합병증 없이 퇴원하였다. 술 후 20 개월째 시행한 전산화단층촬영에서 중심 거대 세포

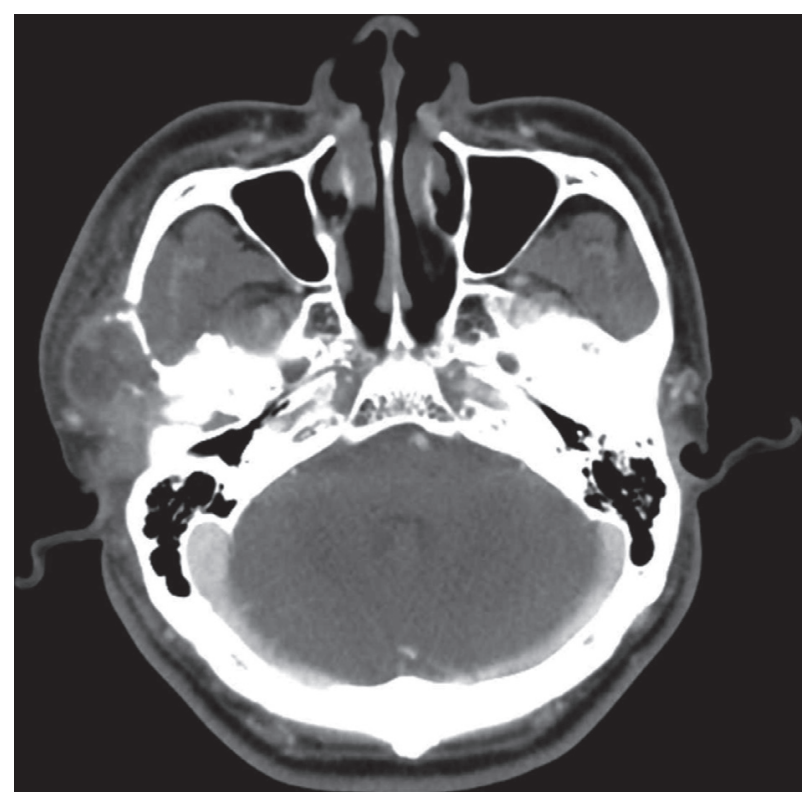

Fig. 1. Neck CT axial scan show about $2.1 \times 1.8 \mathrm{~cm}$ sized heterogenous bony erosive lesion in the right zygomatic bone.
육아종의 재발 소견은 보이지 않았으며, 현재까지 특별한 이 상소견 없이 외래 통원 치료 중이다(Fig. 5).

\section{고 찰}

중심 세포 거대 육아종은 1953 년 Jaffe ${ }^{5}$ 에 의해 처음 기술되 었으며, 처음에는 중심 세포 수복성 거대 육아종이라는 명칭 으로 기술되었으나, 특별한 외상력 없이도 병이 발병하여, 수 복성이라는 명칭은 최근에는 사용하지 않는다.

중심 세포 거대 육아종은 비공격적인 유형과 공격적인 유형 으로 나눌 수 있으며, 공격적인 유형은 진단 당시 좀 더 어리 고, 병변이 광범위하며 비공격적인 유형에 비해 재발이 빈번 한 것으로 알려져 있다. ${ }^{6}$ 대개 20 30대에 발생하는 것으로 알 려져 있고, 문헌상 $74 \%$ 의 환자가 30살 이전에 발병한다고 한 다. ${ }^{7)}$ 일반적으로 여성이 남성보다 2 3배 발병률이 높다고 알 려져 있으나, 이러한 명백한 원인은 아직 밝혀지지 않았다. 따 라서, 본 증례는 평균 발생 연령보다 고령의 남성에서 발생한

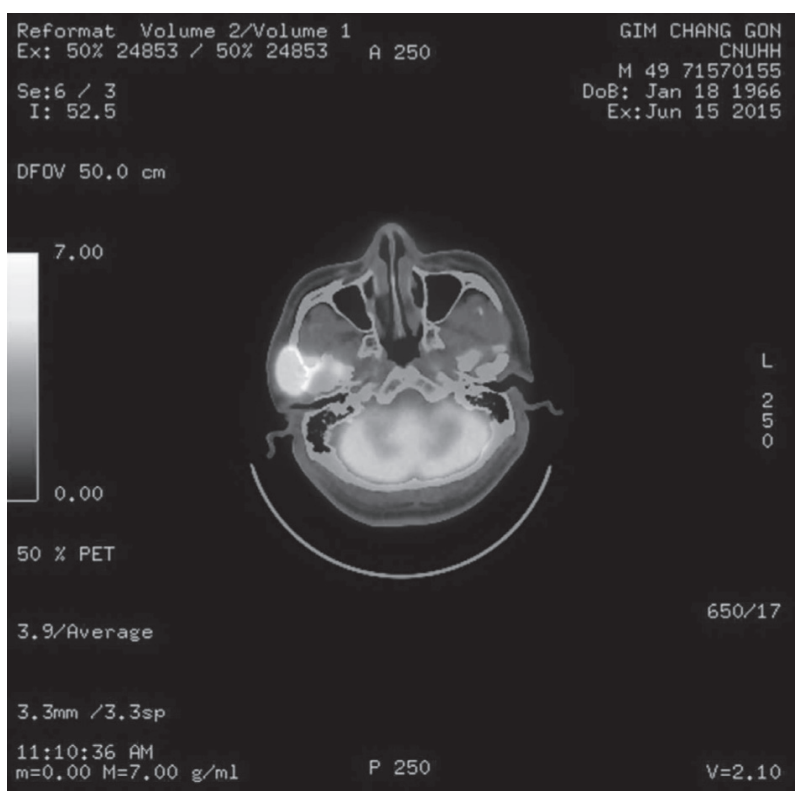

Fig. 2. Torso PET-CT axial scan show about $2.7 \mathrm{~cm}$ sized hypermetabolic lesion in the right zygomatic bone.

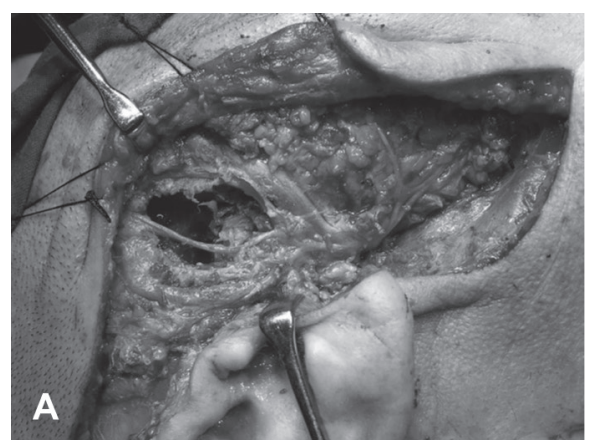

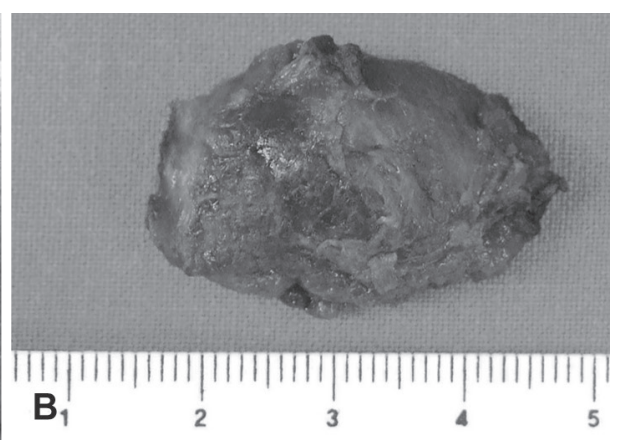

Fig. 3. There are well preserved facial nerve branches in the op field after right superficial parotidectomy and mass removal (A). Surgical specimen (B). 


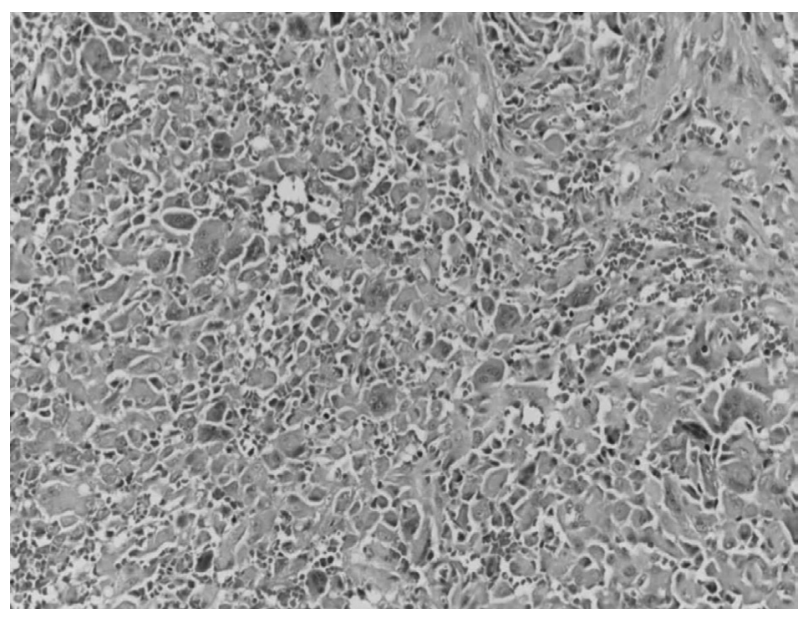

Fig. 4. There are numerous multinucleated osteoclastic giant cells and oval to spindle shaped mononuclear cells at stroma. We can see some fibrous focus, peripheral reactive bone formation with hemorrhage and hemosiderin pigment deposition. There are not atypical mitoses in this cell $(H \& E, \times 200)$.

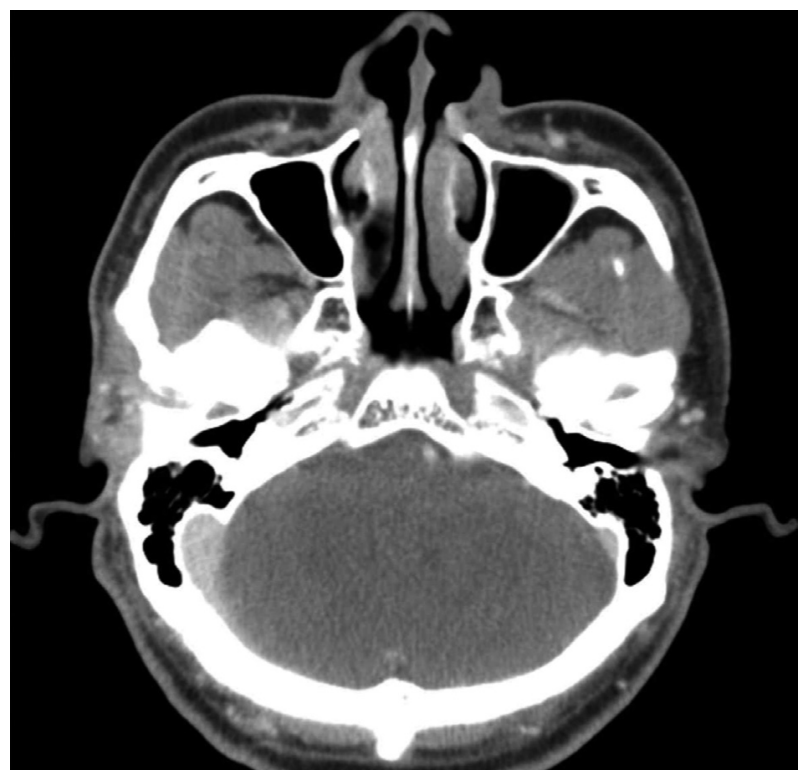

Fig. 5. At the 20 months follow-up, neck CT axial shows no recurrence of central giant cell granuloma.

\section{드문 증례이다.}

병의 유병률이 낮은 관계로 특징적인 영상의학적 소견은 기 술된 바가 없으나, 전산단층화촬영에서는 때때로, 조영이 증 가된 낭 형성, 석회화 및 골 재형성을 보인다. 이러한 병변은 감 염된 점액낭종혹은 다중격낭종과 혼동될 수 있다. 자기공명 영상에서는 $\mathrm{T} 1$ 에서 중간정도의 조영증강을, $\mathrm{T} 2$ 에서 고강도의 조영증강을 보인다. ${ }^{8}$

병리조직학적으로 세포 혈관 기질내부에 다핵의 거대 세포가 새로운 골형성을 이루며 세포 혈관 기질내부에서 관찰된다. 파 골세포와 유사한 거대 세포가 불규칙적인 분포를 보이며 몇
군데에서 출혈이 관찰된다. 방추형의 섬유모세포, 근섬유모세 포와 염증성 단핵구를 포함한 증식성 세포가 관찰된다.,10) 본 질병은 거대 세포 종양, 섬유형성이상, 동맥류 뼈 종양, 부갑 상선의 갈색 종양과 감별을 요한다. 거대 세포 종양은 주로 장 골에 호발하고 20세 이후 성인에게서 통상 발생한다. 섬유형 성이상과 동맥류 뼈 종양은 병리조직학적 소견과 방사선학적 소견으로 감별이 가능하다. ${ }^{11)}$ 부갑상선의 갈색 종양은 병리조 직학적 소견과 방사선학적 소견으로 감별이 어려우나 혈청 칼 슘, 인, 알칼리성 인산염을 측정함으로써 감별이 가능하다. ${ }^{12,13)}$

중심 세포 거대 육아종의 일반적인 치료법은 수술적 절제이 며, 조직 제거의 범위는 간단한 소파술부터 일괄 절제술까지 가능하다. 수술 후 재발률은 11 72\%까지 다양하며 공격적인 유형의 경우 재발률이 더 높다고 알려져 있다.614) 비 수술적 방 법으로는 병변 내 코르티코스테로이드 주입술, 칼시토닌, 인터 페론 알파나 방사선치료가 있으며, 이러한 방법은 추가적인 수 술적 처치가 필요할 가능성이 높기 때문에, 병변의 완전한 절 제가 어려운 경우에 고려할 수 있다. 특히 방사선 치료의 경우 중심 세포 거대 육아종이 방사선에 민감한 특성을 갖기 때문에 수술의 금기증이 되는 환자의 경우 유용한 대안이 될 수 있 다. ${ }^{15)}$ 거대 세포 육아종의 외래 추적 관찰 기간은 저자들에 따 라 수개월에서 수년까지 다양하나, 재발의 가능성이 있으므로 최소 2년 이상은 추적 관찰하는 것이 나으리라 생각된다.

본 증례에서는 술 전에 거대 세포 육아종의 가능성을 생각 하지 못하였고, 전신 마취하에 이하선 천엽 제거술 및 우측 광 대 종물 제거술을 시행하였으며, 수술 후 시행한 조직 검사 결 과가 양성 종양으로 최종 진단되어 추가적인 방사선치료 및 비 수술적치료를 시행하지 않았다.

결과론적으로, 본 증례는 수술적 처치 후 시행한 병리조직 검사에서 중심 거대 세포 육아종을 확진한 예이다. 수술 전에 방사선학적인 검사를 시행하였으나 중심 거대 세포 육아종을 생각하지 못하였다. 그러므로, 중심 거대 세포 육아종이 광대 뼈에도 발생할 수 있음을 염두에 두어야 하겠으며, 중심 거대 세포 육아종이 의심되었을 경우에는 세침흡인검사를 포함한 다양한 검사를 시행하여 정확한 진단 및 치료를 시행해야 할 것이다.

\section{REFERENCES}

1) Lee HM, Kim JK, Ha HB, Cho GS, Yang KH, Park MS. A case of giant cell granuloma of the maxilla. Korean J Otorhinolaryngol-Head Neck Surg 1990;33(5):1007-11.

2) Lee HM, Lee KS, Hwang SJ, Chu KC. A case of giant cell reparative granuloma of the maxilla. Korean J Otorhinolaryngol-Head Neck Surg 1986;29(2):249-52.

3) Lee WY, Paik SI, Jung YG, Kim DS. A case of giant cell graunloma in the maxillary sinus. Korean J Otorhinolaryngol-Head Neck Surg 1996;39(11):1884-9. 
4) Jang HJ, Oh SJ, Cho KS, Roh HJ. A case of giant cell granuloma of maxillary sinus: long-term follow-up. Korean J OtorhinolaryngolHead Neck Surg 2009;52(3):284-8.

5) Jaffe HL. Giant-cell reparative granuloma, traumatic bone cyst, and fibrous (fibro-oseous) dysplasia of the jawbones. Oral Surg Oral Med Oral Pathol 1953;6(1):159-75.

6) Chuong R, Kaban LB, Kozakewich H, Perez-Atayde A. Central giant cell lesions of the jaws: a clinicopathologic study. J Oral Maxillofac Surg 1986;44(9):708-13.

7) Sholapurkar AA, Pai KM, Ahsan A. Central giant cell granuloma of the anterior maxilla. Indian J Dent Res 2008;19(1):78-82.

8) Seo ST, Kwon KR, Rha KS, Kim SH, Kim YM. Pediatric aggressive giant cell granuloma of nasal cavity. Int J Surg Case Rep 2015;16:6770 .

9) Walstad WR, Fields T, Schow SR, McKenna SJ. Expansile lesion of the anterior maxilla. J Oral Maxillofac Surg 1999;57(5):595-9.

10) Ciorba A, Altissimi G, Giansanti M. Giant cell granuloma of the maxilla: case report. Acta Otorhinolaryngol Ital 2004;24(1):26-9.

11) Batsakis JG. Tumors of the head and neck: clinical and pathological considerations. 2nd ed. Baltimore: Williams and Wilkins Co;1979. p.395-404.

12) Waldron CA, Shafer WG. The central giant cell reparative granuloma of the jaws. An analysis of 38 cases. Am J Clin Pathol 1966;45(4): 437-47.

13) Friedman WH, Pervez N, Schwartz AE. Brown tumor of the maxilla in secondary hyperparathyroidism. Arch Otolaryngol 1974;100: 157-9.

14) de Lange J, van den Akker HP, Klip H. Incidence and disease-free survival after surgical therapy of central giant cell granulomas of the jaw in The Netherlands: 1990-1995. Head Neck 2004;26(9):792-5.

15) Hirschl S, Katz A. Giant cell reparative granuloma outside the jaw bone. Diagnostic criteria and review of the literature with the first case described in the temporal bone. Hum Pathol 1974;5(2):171-81. 